SUPPORTING DATA FOR HYDROLOGIC STUDIES IN SAN FRANCISCO BAY, CALIFORNIA: METEOROLOGICAL MEASUREMENTS AT THE PORT OF REDWOOD CITY DURING 1995-1997.

by Laurence E. Schemel

U.S. GEOLOGICAL SURVEY

Open-File Report $98-64$

Menlo Park, California

January 1998 
U. S. DEPARTMENT OF THE INTERIOR

BRUCE BABBITT, secretary

U. S. GEOLOGICAL SURVEY

Thomas J. Casadevall, Acting Director

For additional information write to:

U.S. Geological Survey, WRD 345 Middlefield Road Menlo Park, California 94025
Copies of this report

can be purchased from:

U.S. Geological Survey Information Services Box 25286 Federal Center Denver, Colorado 80225 


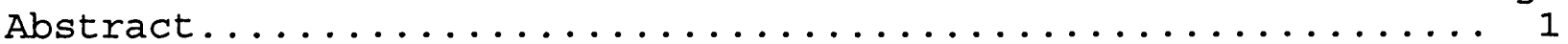

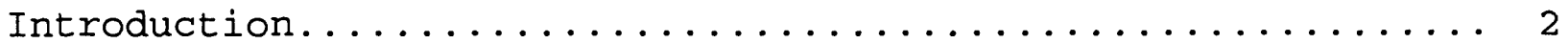

Acknowledgments.......................... 2

Instruments and Methods........................ 4

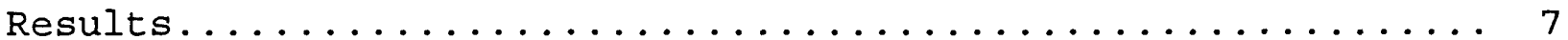

Time Scales of Variability.................. 7

Comparison with Records from other Locations........... 12

Comparison with Values from the new NOAA PORTS station... 12

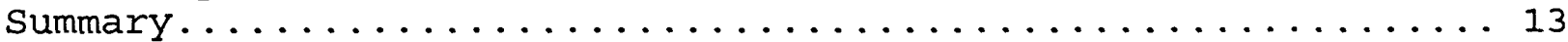

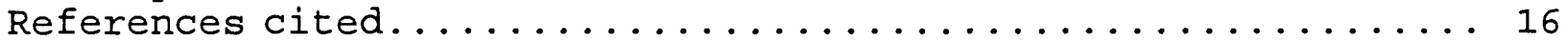

Appendix................................ 17

\section{ILLUSTRATIONS}

Figure 1. Map showing San Francisco Bay and locations in

Page

South San Francisco Bay................... 3

2. Time series plots of daily mean values of temperature, quantum flux (insolation), barometric pressure, and scalar wind speed at the Port of Redwood City, 1995.. 8

3. Time series plots of daily mean values of temperature, quantum flux (insolation), barometric pressure, and scalar wind speed at the Port of Redwood City, 1996.. 9

4. Time series plots of daily mean values of temperature, quantum flux (insolation), barometric pressure, and scalar wind speed at the Port of Redwood City, 1997.. 10

5. Measured and long-term-average (normal) values for monthly total precipitation at San Francisco International Airport, October 1994 -December 1997....... 11

6. Hourly mean wind speeds at the Port of Redwood City measured at the USGS and NOAA meteological stations.. 14

7. Comparison of hourly mean wind speed values measured at the USGS and NOAA meteorlogical stations........ 14

8. Records for barometric pressure from the UGGS and NOAA meteorological stations at the Port of Redwood City...15

9. Records for air temperature from the USGS and NOAA meteorological stations at the Port of Redwood City...15 10-21. Time series plots of hourly mean values for temperature, quantum flux, pressure, mean wind speed, and wind direction at the Port of Redwood City for three-month

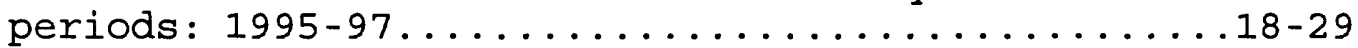


Table 1. Column headers for ASCII files of hourly mean values.. 5

2. Column headers for ASCII files of daily values.......5

3. Components of the temporary meteorological station

at the Port of Redwood City, California............ 6

CONVERSION FACTORS

Metric and inch-pound units are used in this report. Conversion factors to other commonly-used units are provided below for the measurements made in this study.

Multiply

statute miles per hour millibars millibars
By

0.447

0.0295

0.0145
To obtain

meters per second inches of mercury pounds per square inch

Temperature is given in degrees Celsius $\left({ }^{\circ} \mathrm{C}\right)$ and can be converted to degrees Fahrenheit $\left({ }^{\circ} \mathrm{F}\right)$ using the following equation:

$$
\left({ }^{\circ} \mathrm{F}\right)=1.80\left({ }^{\circ} \mathrm{C}\right)+32
$$

The use of brand names in this report is for identification purposes only and does not constitute endorsement by the U.S. Geological survey. 


\title{
SUPPORTING DATA FOR HYDROLOGIC STUDIES IN SAN FRANCISCO BAY, CALIFORNIA: METEOROLOGICAL MEASUREMENTS AT THE PORT OF REDWOOD CITY DURING 1995-97
}

by Laurence E. Schemel

\begin{abstract}
Meteorological data were collected during 1995-97 at the Port of Redwood City, California, to support hydrologic studies in South San Francisco Bay. The meteorological variables that were measured were air temperature, atmospheric pressure, quantum flux (insolation), and four parameters of wind speed and direction: scalar mean horizontal wind speed, (vector) resultant horizontal wind speed, resultant wind direction, and standard deviation of the wind direction. Hourly mean values based on measurements at fiveminute intervals were logged at the site, then transferred monthly to a portable computer. Daily mean values were computed for temperature, insolation, pressure, and scalar wind speed. All data are provided in ASCII files on an IBM-formatted disk. Time series plots of the data are presented in the report with a brief overview of seasonal variations and unusual events.
\end{abstract}




\section{INTRODUCTION}

The U.S. Geological survey (USGS) collects many types of environmental data to support hydrologic studies of the san Francisco Bay estuarine system. These include the collection of meteorological data, because weather and climate variables can greatly affect physical, biological and chemical processes in bay waters (for example, Schemel and Hager 1996). A temporary meteorological station was established by USGS at the Port of Redwood City (RWC) in April 1992 to support research and monitoring activities in this region (fig. 1). Measurements from this station have been useful in identifying links between weather and climate and hydrologic variables in studies conducted by the U.S. Geological Survey in cooperation with the California Department of Water Resources (Sacramento, CA), the California state water Resources Control Board, and the Regional Water Quality Control Board (Oakland, $C A$ ). In addition, the data are utilized in ongoing studies of San Francisco Bay by the U.S. Geological Survey National Research Program and by researchers at Stanford University. Data through December 1994 were reported by Schemel (1995). This report presents the data for January 1995 through December 1997.

Wind speed and direction are particularly important variables, because winds from specific directions induce strong surface and bottom currents and mix the water column in the bay. This was a primary reason for installation of the meteorological station in 1992, when few measurements were available for South San Francisco Bay. Recently, development of a regional-scale wind model has led to the availability of real-time and historical wind measurements and predictions (http://sfbay7.wr.usgs.gov/wind and links therein). other sources of weather and climate information for the san Francisco Bay area now include California Data Exchange Center (http://cdec.water.ca.gov) and National Weather Service (http://www.nws.mbay.net) sites on the World Wide Web. In addition, the National Oceanic and Atmospheric Administration (NOAA) installed tide-height and weather sensors at the Port of Redwood City in late 1997, as part of the real-time-data PORTS system (see below). With these new sources of data now on-line, it is likely that the USGS temporary meteorological station at RWC will be moved to another location sometime after January 1998 .

\section{Acknowledgments}

Cooperation and assistance by S.L. Wallace, director of the USGS Marine Facility at Redwood City, is appreciated. Reviews of the manuscript by M.H.Cox and J.W. Gartner are also appreciated. 


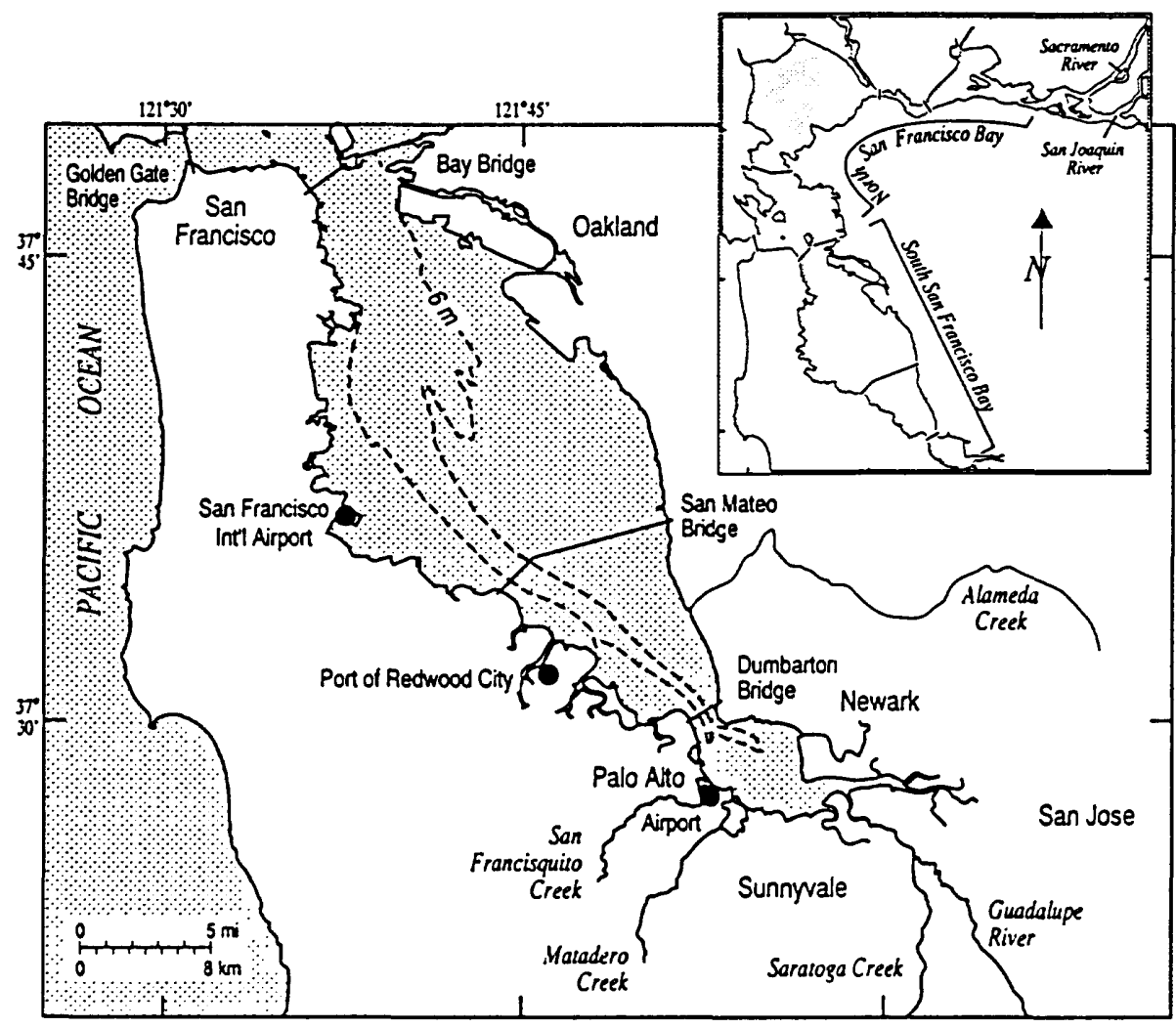

Figure 1. Map showing San Francisco Bay and locations in South San Francisco Bay. 


\section{INSTRUMENTS AND METHODS}

Meteorological variables were measured at the USGS Marine Facility at the Port of Redwood City, which is located near the west side of South San Francisco Bay (fig. 1). Instruments were mounted on a 2m-high tripod located on the roof of the Marine Facility building. This building is approximately $100 \mathrm{~m}$ west of the Port of Redwood City administration building. The elevation of the instrument array above grade was approximately $15 \mathrm{~m}$. A large topographic obstruction, such as the Marine Facility building is expected to have some effect on wind speed and perhaps other meteorological variables. Although this is not expected to cause large errors at this location, effects were not quantified. Comparisons with wind speed measurements at Palo Alto and San Francisco International Airport (SFO) are described by Schemel (1995), and comparisons with recent data from the new NOAA PORTS station are shown in this report.

The meteorological variables that were measured from January 1995 through December 1997 are listed in table 1 in the order that they are provided in the files containing hourly-mean data. Similarly, column headers for data files containing daily-mean and daily-total values are listed in table 2. All hourly and daily values were based on measurements made at five-minute intervals.

All instruments and sensors were factory calibrated, and no further calibrations or assessments of the quality of the data were made (table 3 ). Measurements were made at five-minute intervals, then averaged or otherwise processed (see below) to provide values for the preceding 60 minutes. Data were logged on the hour (Pacific Standard Time) at the site by a Campbell scientific Company CR10, then downloaded monthly to a personal computer. The data-logging program for the CR10 was developed using software provided by the manufacturer.

Data for wind speed and direction were collected according to recommendations made by the Environmental Protection Agency for regulatory modeling applications. This provides scalar mean horizontal wind speed as well as (vector) resultant mean horizontal wind speed. Resultant mean wind direction and the standard deviation of wind direction are also provided by the output processing instruction.

A quantum sensor was used to measure insolation (solar irradiance). This sensor measures quantum fluxes in moles (6.02 $\mathrm{x}$ $10^{23}$ photons $=$ one Einstein) over the visible spectrum. 
Table 1. Column headers for ASCII files of hourly mean values.

\begin{tabular}{cll}
\hline $\begin{array}{c}\text { Column Number } \\
\text { (in sequence) }\end{array}$ & \multicolumn{1}{c}{ Measurement } & Units \\
\hline & & \\
1 & Program version & none \\
3 & Day of calendar year & none \\
4 & Pacific Standard Time & hours \\
5 & Insolation (quantum flux) & $10^{-6} \mathrm{moles} \mathrm{m}^{-2} \mathrm{~s}^{-1}$ \\
6 & Temperature & degrees Celsius \\
7 & Barometric pressure & 10 bars \\
8 & Scalar mean wind speed & statute miles h-1 \\
9 & Resultant mean wind speed & statute miles h-1 \\
10 & Unit vector mean wind direction & degrees true \\
& Standard deviation of direction & degrees
\end{tabular}

Table 2. Column headers for ASCII files of daily values.

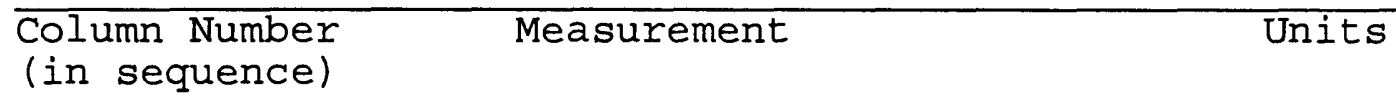

$\begin{array}{ll}1 & \text { Day of calendar year } \\ 2 & \text { Mean irradiance (quantum flux) } \\ 3 & \text { Mean temperature } \\ 4 & \text { Mean barometric pressure } \\ 5 & \text { Scalar mean wind speed } \\ 6 & \text { Total insolation }\end{array}$

none

$10^{-6}$ moles $\mathrm{m}^{-2} \mathrm{~s}^{-1}$ degrees Celsius $10^{-3}$ bars

statute miles $h^{-1}$ moles $\mathrm{m}^{-2} \mathrm{~d}^{-1}$ 
Table 3. Components of the temporary meteorological station at the Port of Redwood City, California.

Components Manufacturer

Wind Monitor, Model 05103

R.M. Young Company

2801 Aero-Park Drive

Traverse City, MI 49884

Barometric Pressure Sensor, Model PTA-427

Vaisala Sensor Systems

100 Commerce Way

Woburn, MA 01801

Quantum Flux (Irradiance) Sensor, Model LI-190SZ

LI-COR, Inc

P.O. Box 4425

Lincoln, Nebraska 68504

Temperature Probe, Model 107

Measurement and Control Module, Model CR10

Tripod with crossarm and irradiance sensor platform, Model CM6 Optically Isolated RS232 Interface, Model SC32A

PC208 datalogger support software package

Campbell Scientific

P.O. Box 551

Logan, UT 84321 


\section{RESULTS}

Time-series plots of daily mean values for temperature, insolation (quantum flux), (barometric) pressure, and (scalar) wind speed are shown for each year in figures 2-4. Time-series plots of the hourly-mean values, including wind direction, are provided for three-month periods in the appendix figures. Data files containing hourly-mean and daily-mean values are provided on the IBM-formatted disk. Description of the data here is limited to major annual, seasonal, and event-scale (a few days) variations. The reader is referred to other sources for general information on the seasonal weather and micro-climatology of the San Francisco Bay area (for example: Gilliam, 1962; Elford, 1970).

\section{Time scales of Variability}

Although differences in annual patterns among years were apparent (interannual variability), most of the meteorological variables clearly showed seasonal changes and annual cycles (figs. 2-4), as well as sometimes-large daily variations (see appendix figures). Seasonal variations in temperature and insolation (quantum flux) followed the annual solar cycle with warmest (daily mean) air temperatures in summer and coolest temperatures near the winter solstice. Variations on the order of hours to days were related to the daily solar cycle, the daily cycle of coastal fog cover during summer, and intermittant cloudiness. Seasonal differences were also observed in pressure and wind speed, but these were related primarily to characteristics of the shorter-term variations. Short-term variability in pressure during the winter storm season was generally much greater than during summer. Similarly, wind speeds showed greatest day-to-day variations over winter and early spring, with the highest speeds most often related to the passing of storm fronts. This is shown by strong winds initially from the south (180 degrees true) followed by winds from the north (see appendix figures). With the exception of storms, however, daily mean wind speeds were generally highest during late spring and summer. Strong afternoon winds that developed during summer were related to air circulation between the cool Pacific Ocean and the warm central valley of California.

Storms during the late autumns through springs of 1995-1997 provided much-needed rainfall following a period dominated by dry years that extended back to 1986. Rainfall (precipitation) at SFO was above normal for these three years, although there were significant differences in the rainfall patterns among the years (fig. 5). Strong winds, low pressures, and temperature changes typically accompanied these storms. A few examples of important meteorological events during the storm seasons of 1995-1997 are described below. 

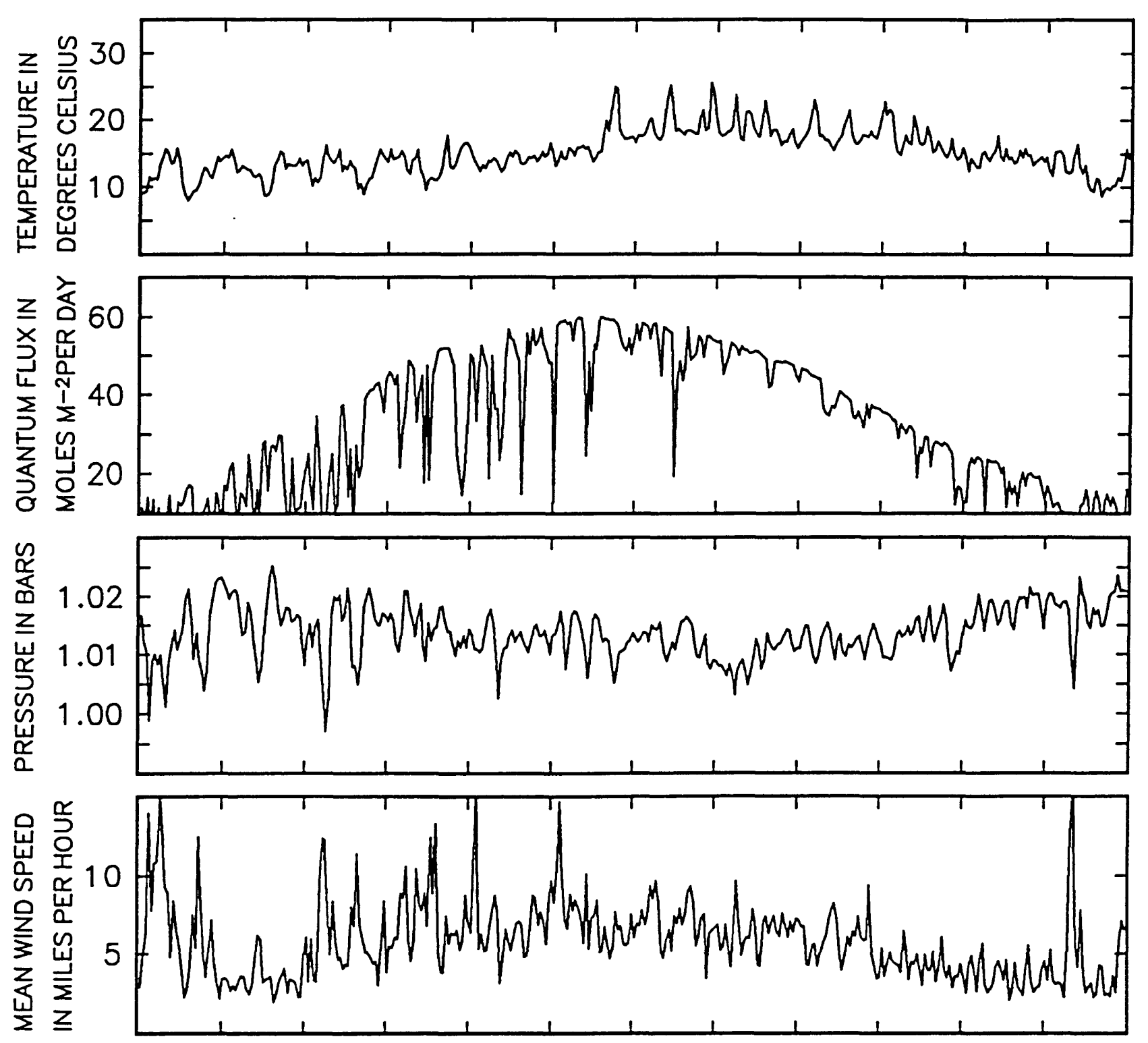

JAN FEB MARAPR MAY JUN JUL AUG SEP OCT NOV DEC DAILY MEAN VALUES FOR 1995

Figure 2. Time series plots of daily mean values of temperature, quantum flux (insolation), barometric pressure, and scalar wind speed at the Port of Redwood City, 1995. 

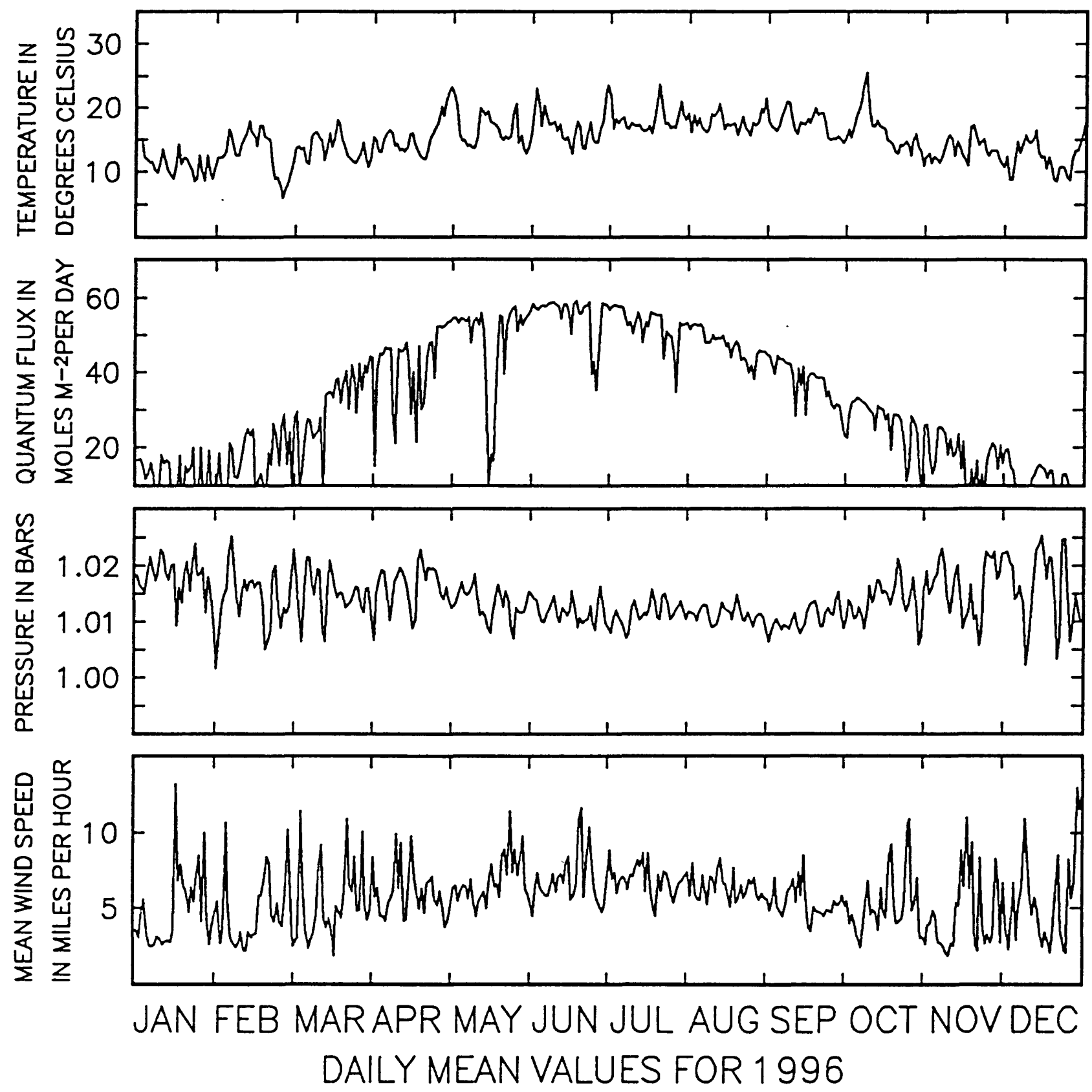

Figure 3. Time series plots of daily mean values of temperature, quantum flux (insolation), barometric pressure, and scalar wind speed at the Port of Redwood City, 1996. 

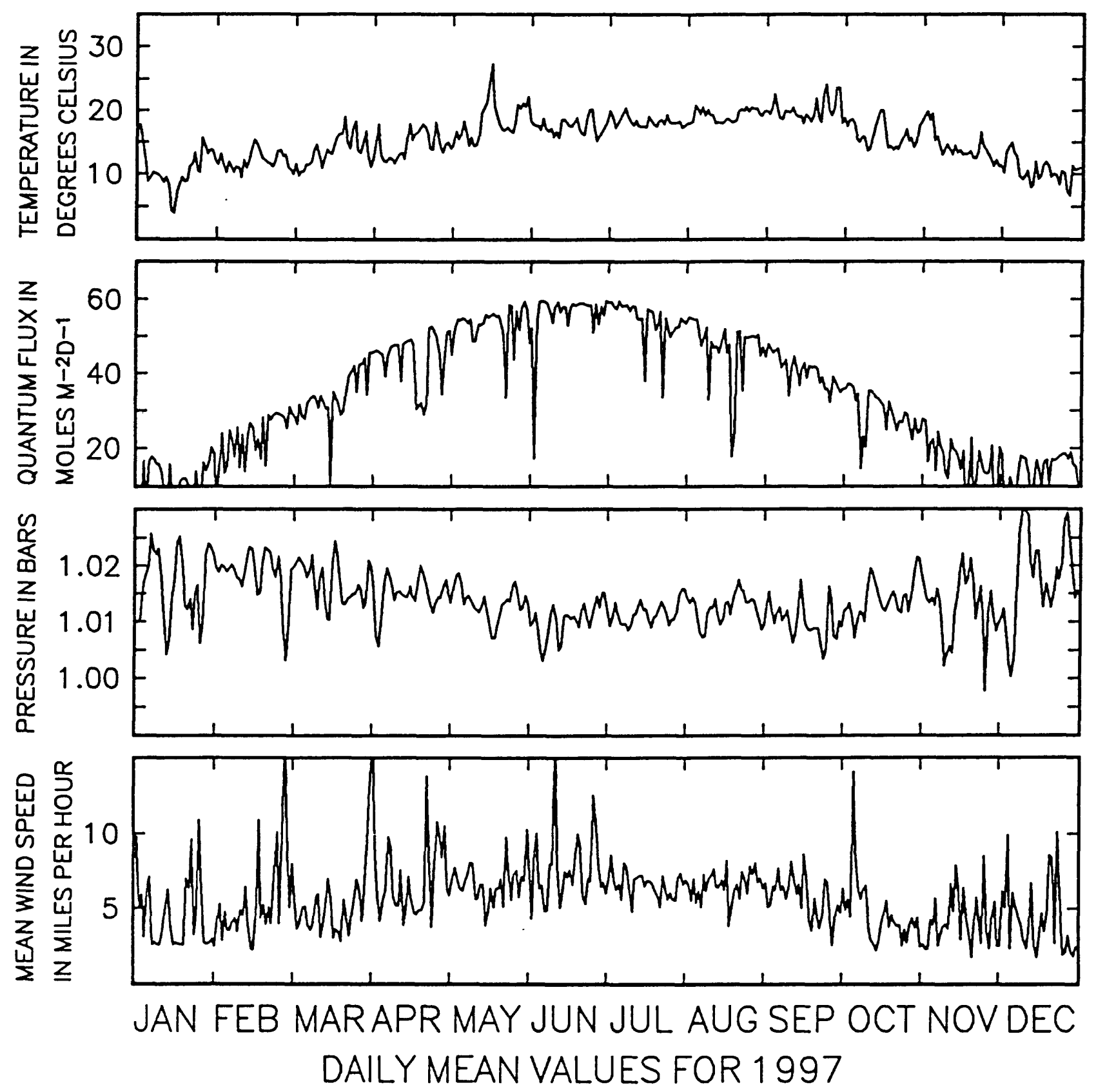

Figure 4. Time series plots of daily mean values of temperature, quantum flux (insolation), barometric pressure, and scalar wind speed at the Port of Redwood City, 1997. 


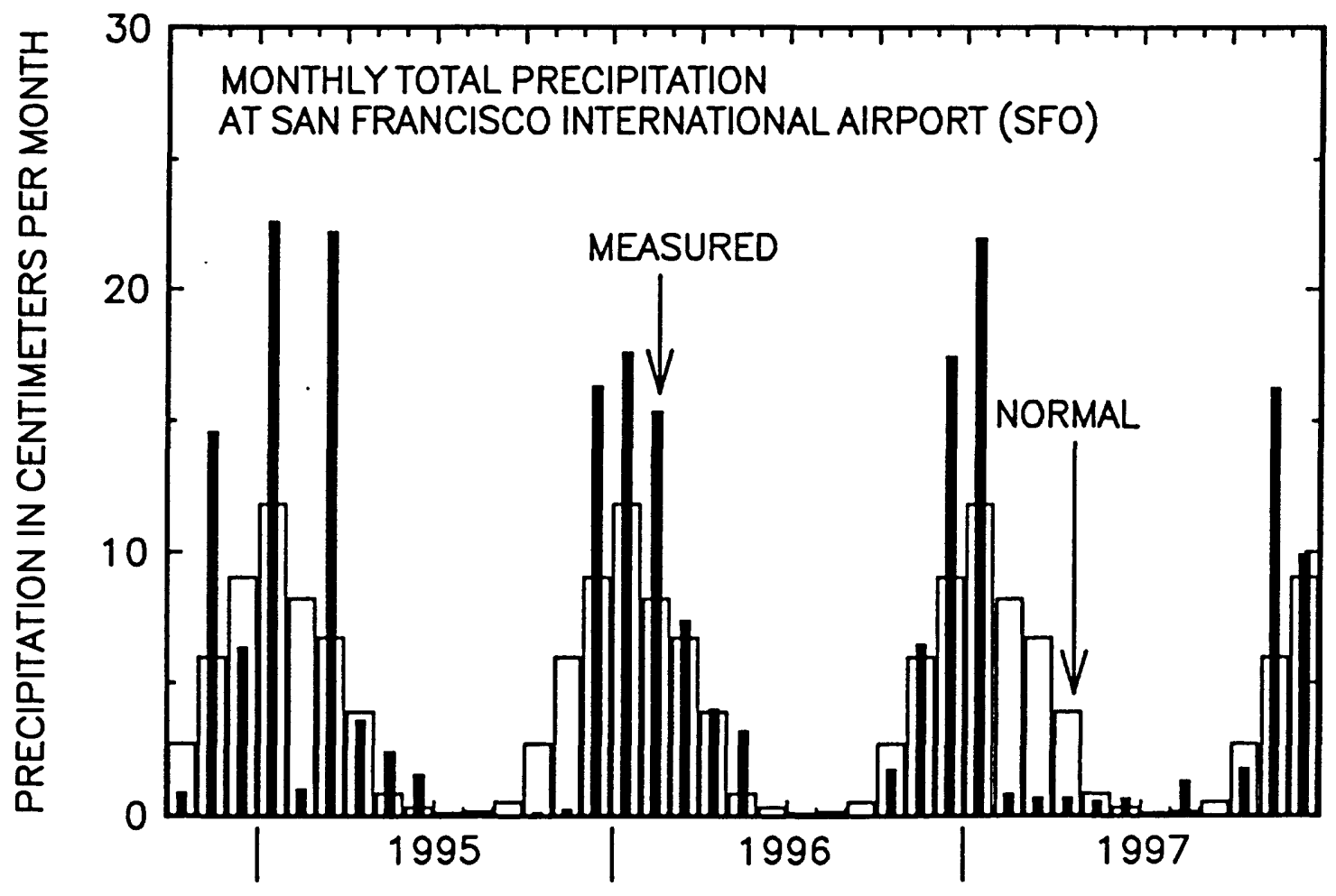

Figure 5. Measured and long-term-average (normal) values for monthly total precipitation at San Francisco International Airport, October 1994 -December 1997. Data are from http://monsoon.water.ca.gov/cgi-bin/precip/. 
Major flooding in San Jose resulted from record flows in the Guadalupe River during January 1995. Strong winds from the south and very low pressures were associated with this storm system (figs. 2 and 10). During a similar storm in March 1995, winds were sufficiently strong to dominate current patterns in the waters of South San Francisco Bay and cause major changes in water-column chemistry (Gartner and others, 1997; Schemel and Knowles, 1997). A complex weather pattern brought hurricane-force winds to San Francisco Bay and the Pacific Northwest during December 1995 (figs. 2 and 13; see http://tornado.sfsu.edu/geosciences/wind.html, and also /rain.html). Record flooding in central and northern California resulted from a series of warm rainstorms that yielded excessive precipitation and melted snowpack over December 29January 4, 1997 (http://water.wr.usgs.gov/flood97/; Kiester, 1997; figs $3,4,17$, and 18).

\section{Comparisons with Records from Other Locations}

Measurements at RWC were compared to observations at other locations in the 1992-1994 data report (Schemel, 1995). The findings are reviewed here because they apply to the records presented in this report. Comparisons of air temperatures at RWC with measurements made at the San Francisco International Airport (SFO, fig. 1) showed that most daily mean values for temperature agreed within one- to two-tenths of a degree Celsius. Daily mean wind speeds at RWC were typically about half the values at the SFO. During summers, the differences resulted from stronger wind speeds at the SFO occurring over longer periods of each day. A comparison of hourly wind speeds at the Palo Alto Municipal Airport (fig. 1) with those at RWC showed that values were similar in magnitude. These comparisons are consistent with predicted regional patterns of wind speed (see http://www.sfbay7.wr.usgs.gov/wind).

\section{Comparison with Values from the new NOAA PORTS station at the Port of Redwood City}

The NOAA PORTS station is located approximately $100 \mathrm{~m}$ west of the UGSG temporary meteorlogical station. The height of the sensors at the NOAA station is about $5 \mathrm{~m}$ lower than the USGS station. Instantaneous measurements are transmitted from the NOAA station every 6 minutes, whereas only hourly mean values are recorded at the USGS station. Hourly mean values were computed from the NOAA data for the wind speed comparisons shown below. 
A 5-day record of wind speed from November 1997 is shown in figure 6. Major features of the variability are comparable between the two sets of measurements except that the USGS station tended to record higher values when wind speeds were low and the NOAA station recorded higher values during a few episodes of high wind speeds. The tendency for USGS values to be higher when wind speeds were low is shown in figure 7. This might be explained by the greater height of the USGS station. The line in this figure represents a 1:1 relationship. At wind speeds above about 5 miles per hour, data are scattered about the line, but a tendency for the NOAA station to record higher values is apparent. An analysis that includes wind direction might be necessary to explain the differences between the values at high wind speeds.

Barometric pressure values are shown in figure 8 . Both stations show the variation over the 5-day period in a similar manner, but values from the NOAA station were consistently higher by about 3 millibars. Temperature values shown by both stations were very similar (fig. 9). Values from the NOAA station show more detail because they were recorded at 6-minute intervals.

\section{SUMMARY}

The USGS has collected hourly values for insolation (quantum flux), air temperature, barometric pressure, scalar mean wind speed, resultant (vector-averaged) mean wind speed, mean wind direction, and standard deviation of wind direction at the port of Redwood City since April 1992. Hourly measurements and daily mean values for the 1995-1997 calendar years are described and compared to data from other sources in this report. In addition, hourly and daily mean values are provided in ASCII files on an IBM-formatted disk. Subsequent data from the Port of Redwood City will be available through the National Oceanographic and Atmospheric Administration at their real-time-data PORTS system sites on the World Wide Web. 


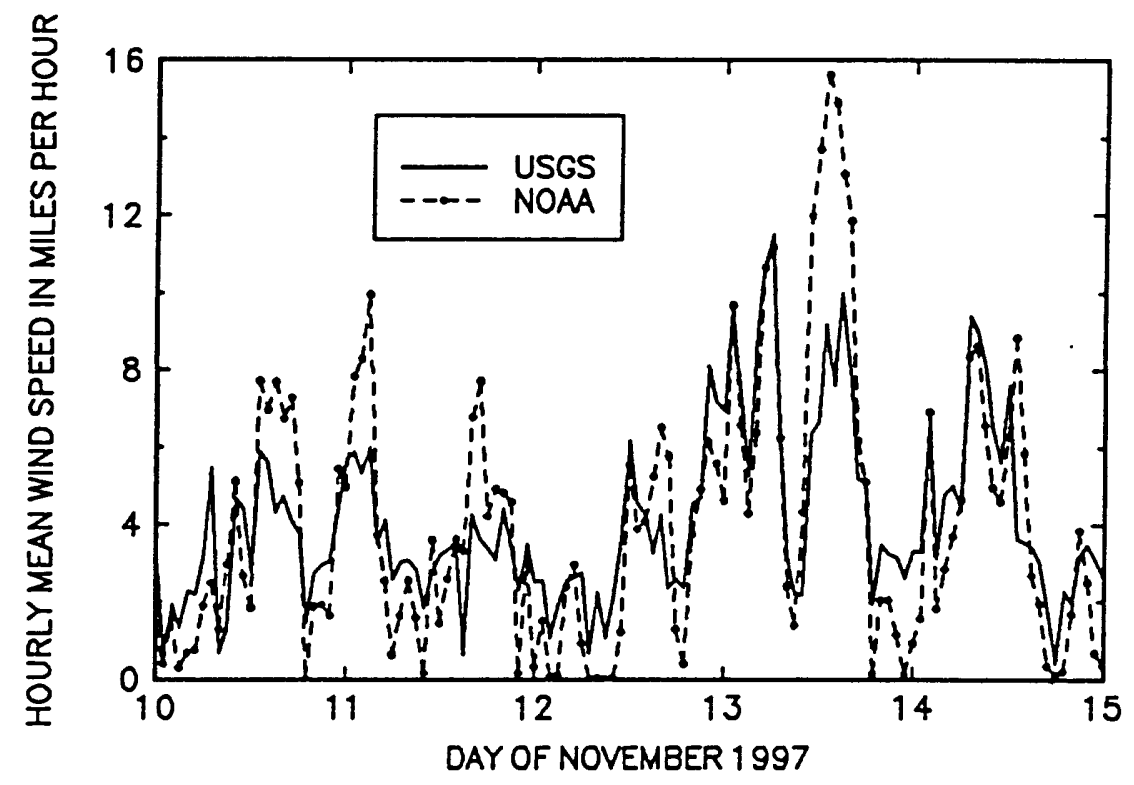

Figure 6. Hourly mean wind speeds at the Port of Redwood City measured at the USGS and NOAA meteorologic al stations.

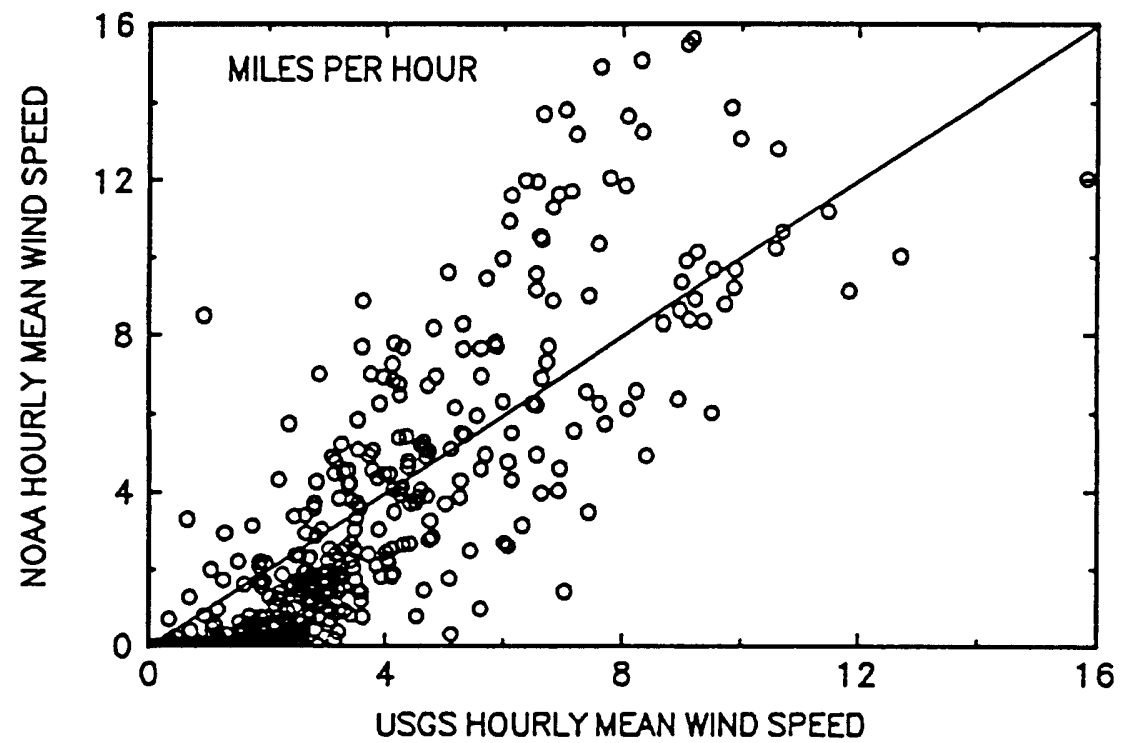

Figure 7. Comparison of hourly mean wind speed values measured at the USGS and NOAA meteorological stations. 


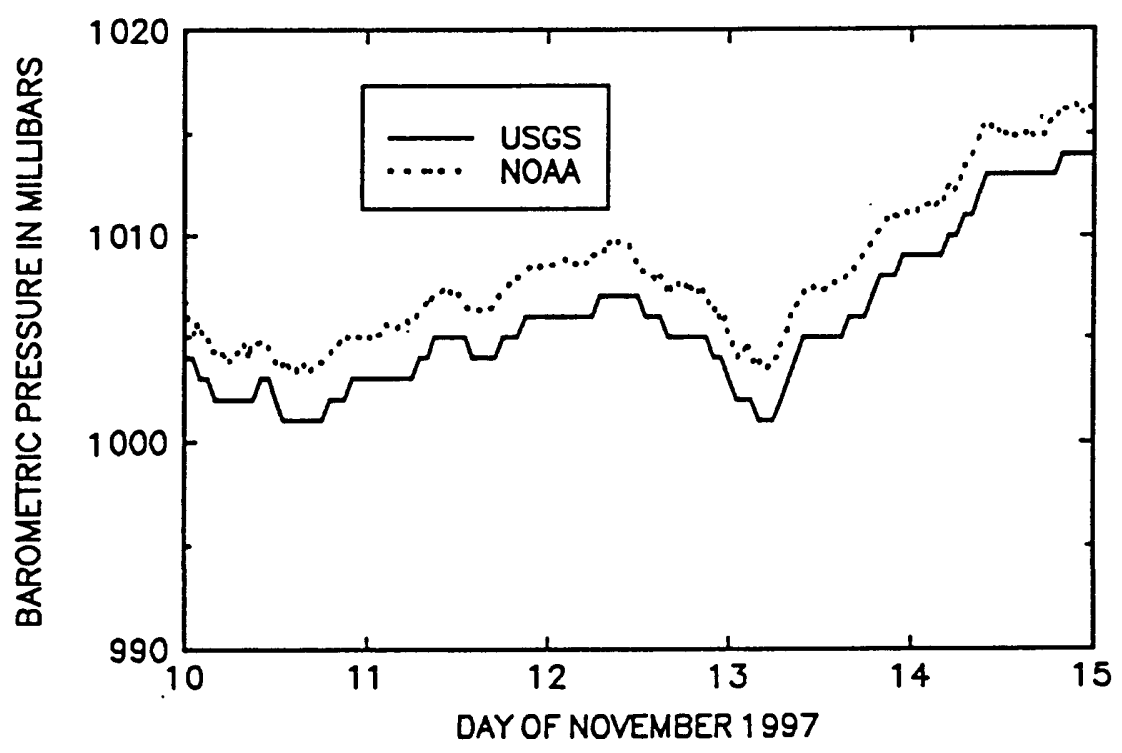

Figure 8. Records for barometric pressure from the USGS and NOAA meteorologic al stations at the Port of Redwood City.

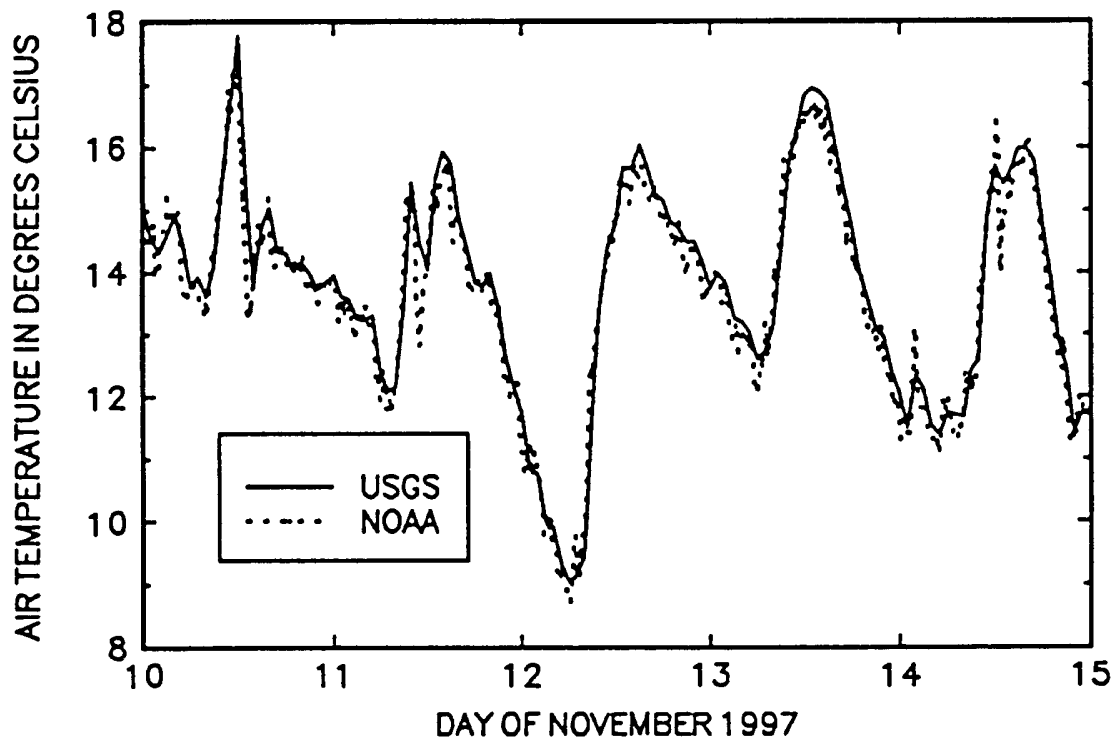

Figure 9. Records for air temperature from the USGS and NOAA meteorologic al stations at the Port of Redwood City. 


\section{REFERENCES CITED}

Elford, C.R., 1970, The climate of California, in Climates of the States, Vol.II: Western states including Alaska and Hawaii: National Oceanic and Atospheric Administration, U.S. Department of Commerce, p.538-546.

Gartner, J.W., Cheng, R.T., Cacchione, D.A., and Tate, G.B., 1997, Near Bottom Velocity and Suspended Solids Measurements in San Francisco Bay, California: in Holly, F.M.Jr. and Alsaffar, Adnan (eds), Environmental and Coastal Hydraulics: Protecting the Aquatic Havitat, v2, p.1090-1095.

Gilliam, Harold, 1962, Weather of the San Francisco Bay Region: University of California Press, Berkeley and Los Angeles, California, $72 \mathrm{p}$.

Kiester, Edwin, Jr., 1997, Water, Water, Everywhere: Smithsonian, August 1997, v.25, no.5, p.35-44.

Schemel, L.E. 1995. Supporting Data for hydrological studies in San Francisco Bay, California: Meteorological Measurements at the Port of Redwood City during 1992-1994: U.S. Geological Survey Open-file Report 95-327, 30p.

Schemel, L.E. and Hager, S.W., 1996, Dissolved inorganic nitrogen, phosporus, and silicon in South San Francisco Bay. II. A case study of effects of local climate and weather: in Hollibaugh, J.T., (ed.), San Francisco Bay: The Ecosystem, Pacific Division, American Association for the Advancement of Science, San Francisco, CA, p.217-236.

Schemel, L.E. and Knowles, Noah, 1997, Simulations and observations of salinity in south San Francisco Bay, CA, 1995: Effects of freshwater discharges, tides, and winds: in Abstracts: Aquatic Sciences Meeting, February 1997, American Society of Limnology and Oceanography, Santa Fe, NM, p.296. 


\section{APPENDIX}

Figures 10-21. Time series plots of hourly values for mean temperature, quantum flux, pressure, mean wind speed, and wind direction at the Port of Redwood City for three-month periods: 1995-1997. 

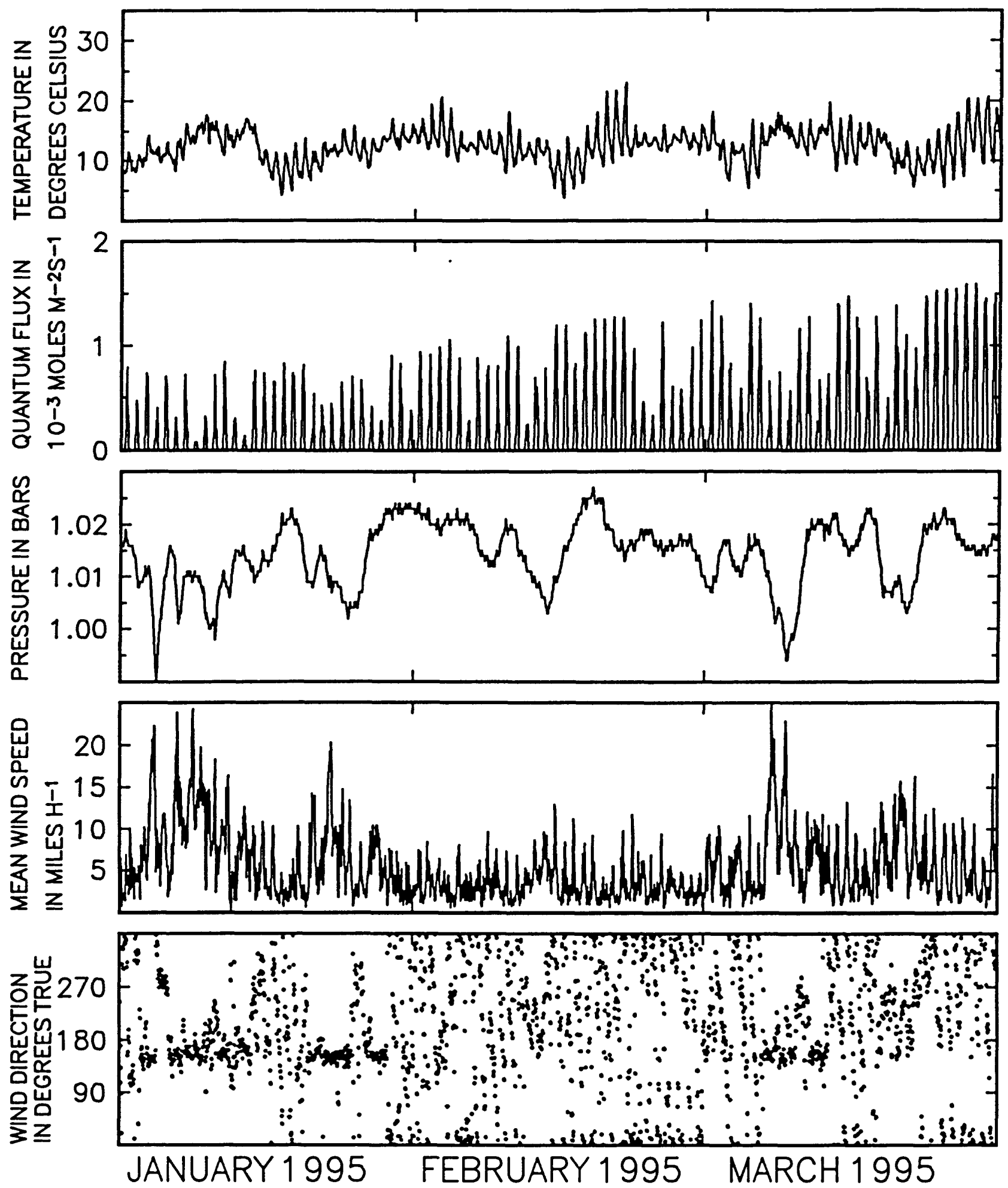

Figure 10. Time series plots of hourly values for mean temperature, quantum flux, pressure, mean wind speed, and wind direction at the Port of Redwood City for January-March, 1995. 

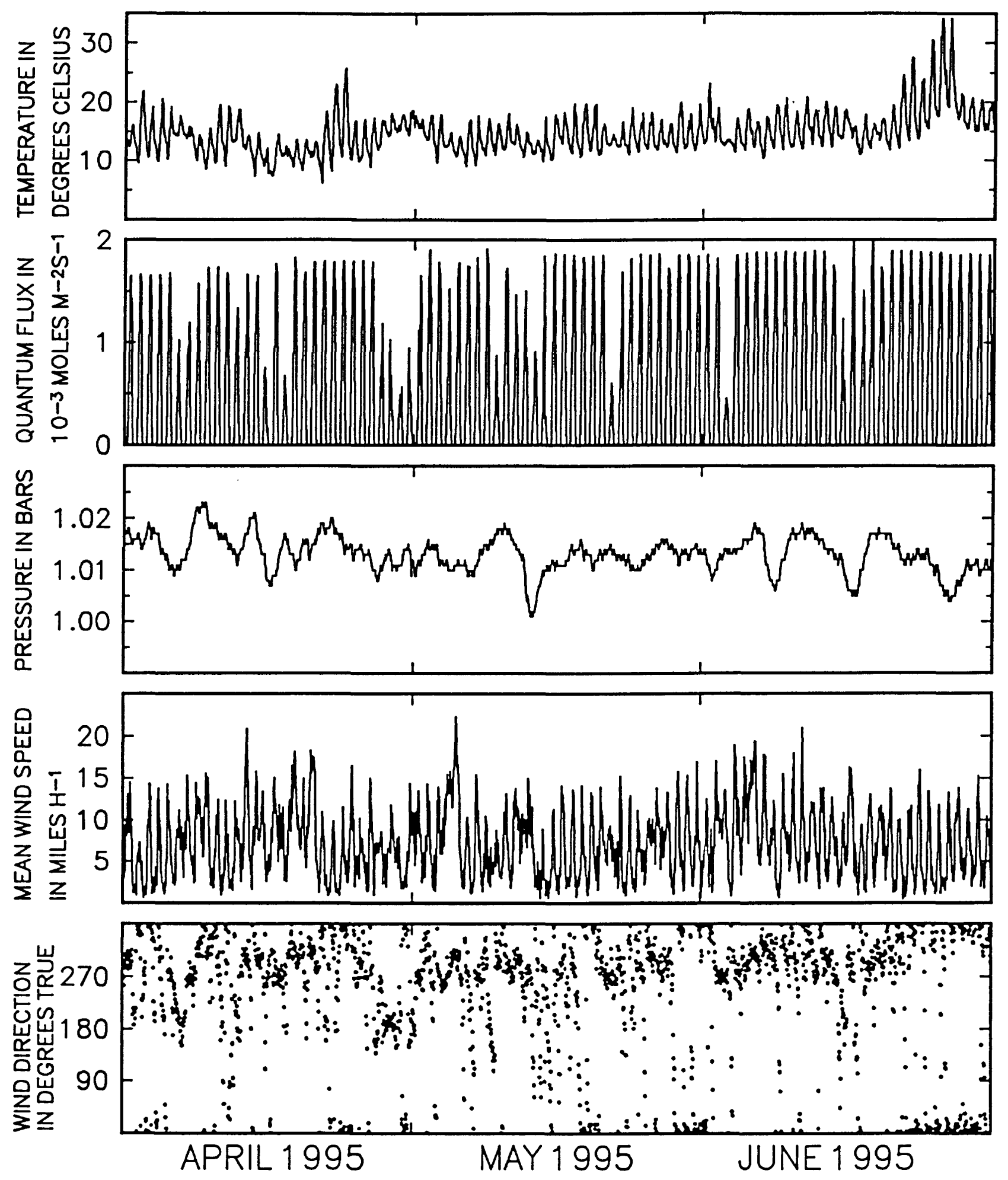

Figure 11. Time series plots of hourly values for mean temperature, quantum flux, pressure, mean wind speed, and wind direction at the Port of Redwood City for April-June, 1995. 

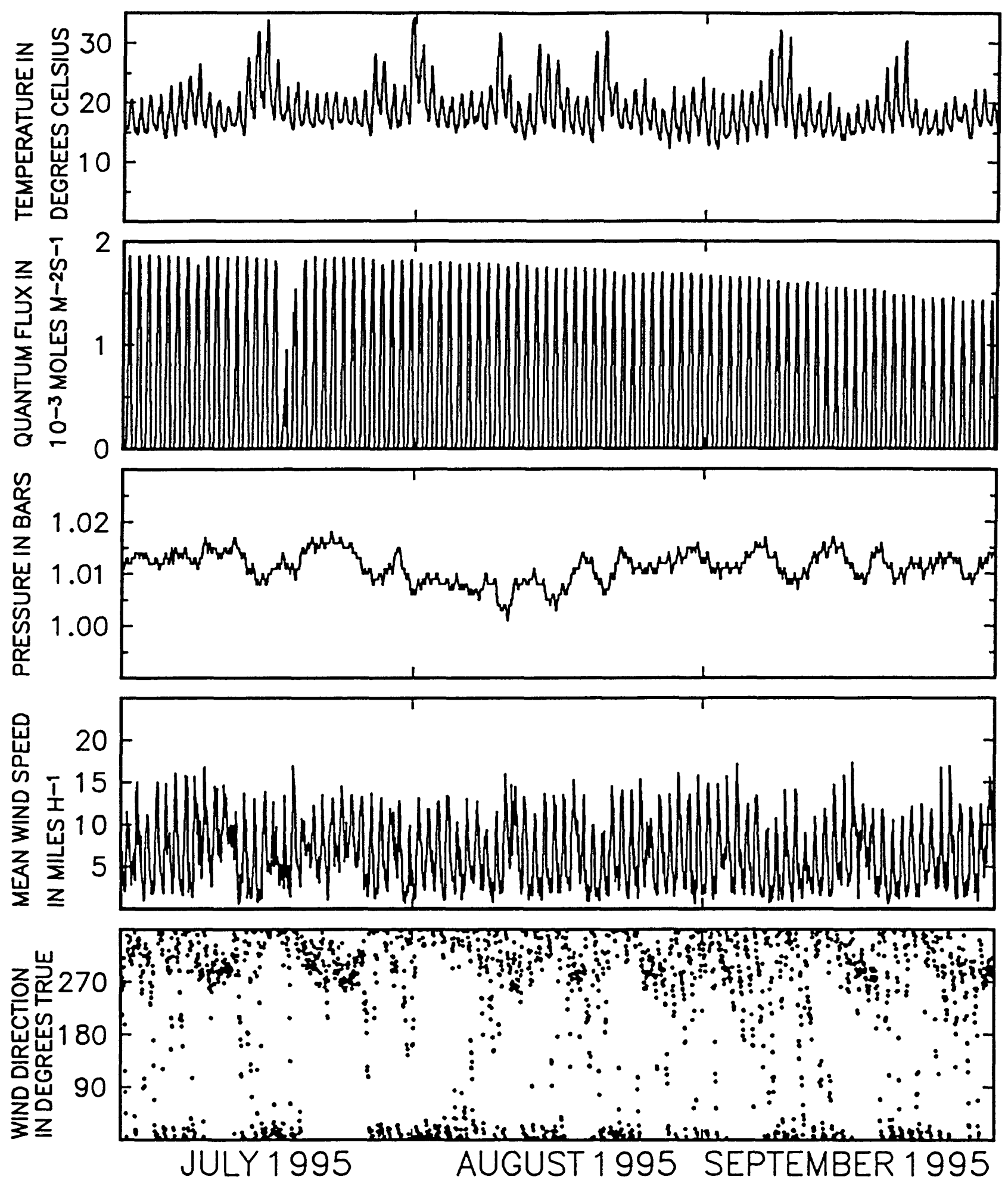

Figure 12. Time series plots of hourly values for mean temperature, quantum flux, pressure, mean wind speed, and wind direction at the Port of Redwood City for July-September, 1995. 

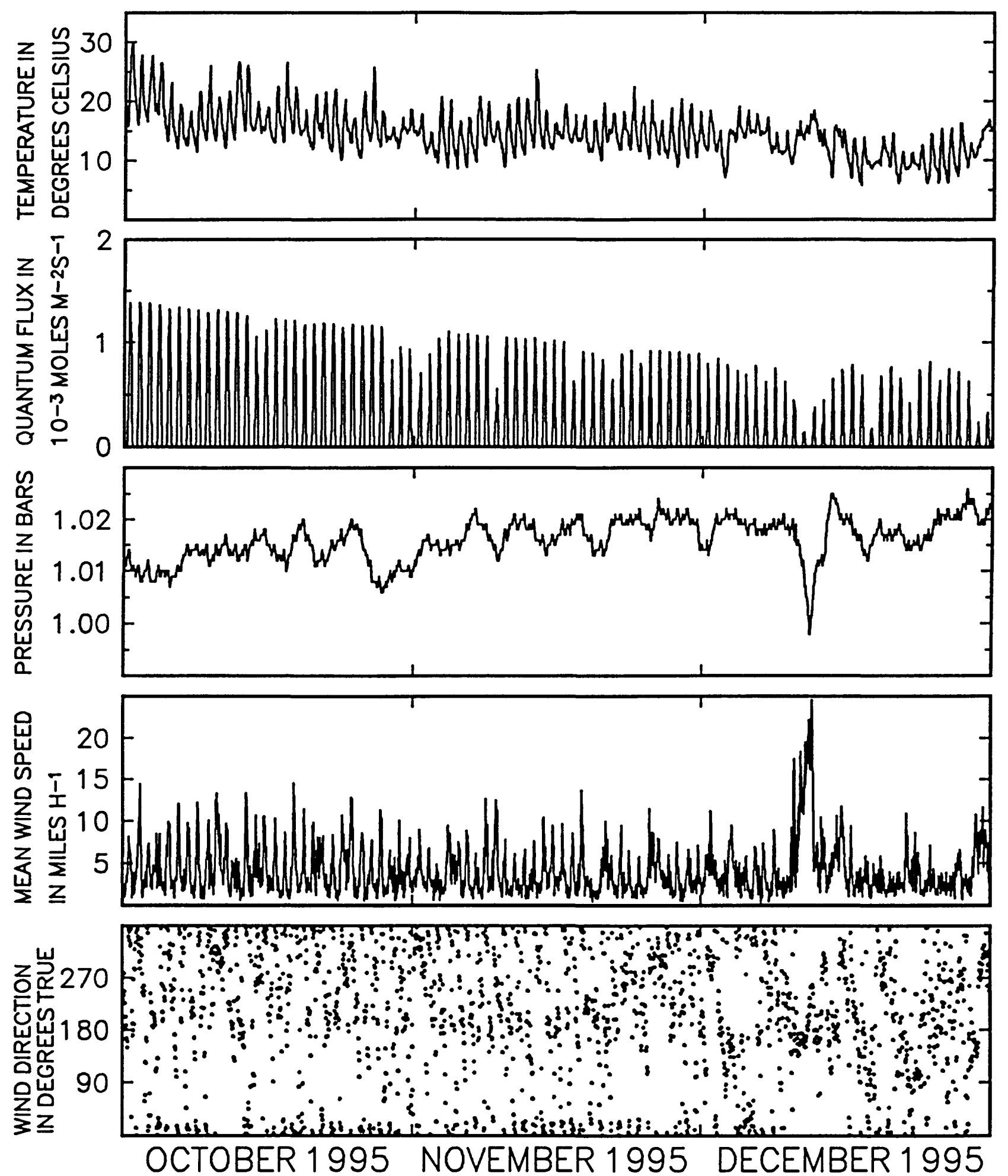

Figure 13. Time series plots of hourly values for mean temperature, quantum flux, pressure, mean wind speed, and wind direction at the Port of Redwood City for October-December, 1995. 

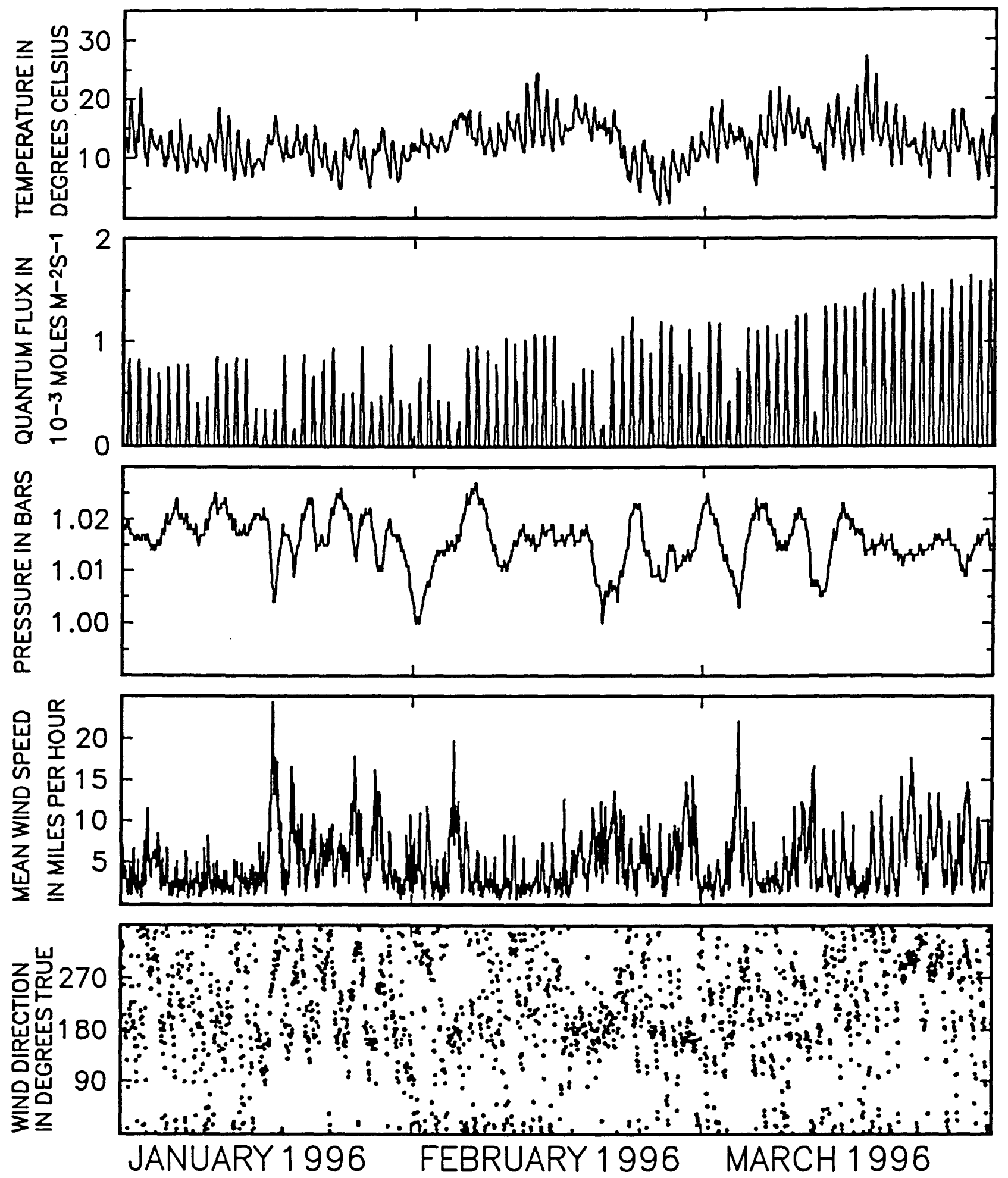

Figure 14. Time series plots of hourly values for mean temperature, quantum flux, pressure, mean wind speed, and wind direction at the Port of Redwood City for January-March, 1996. 

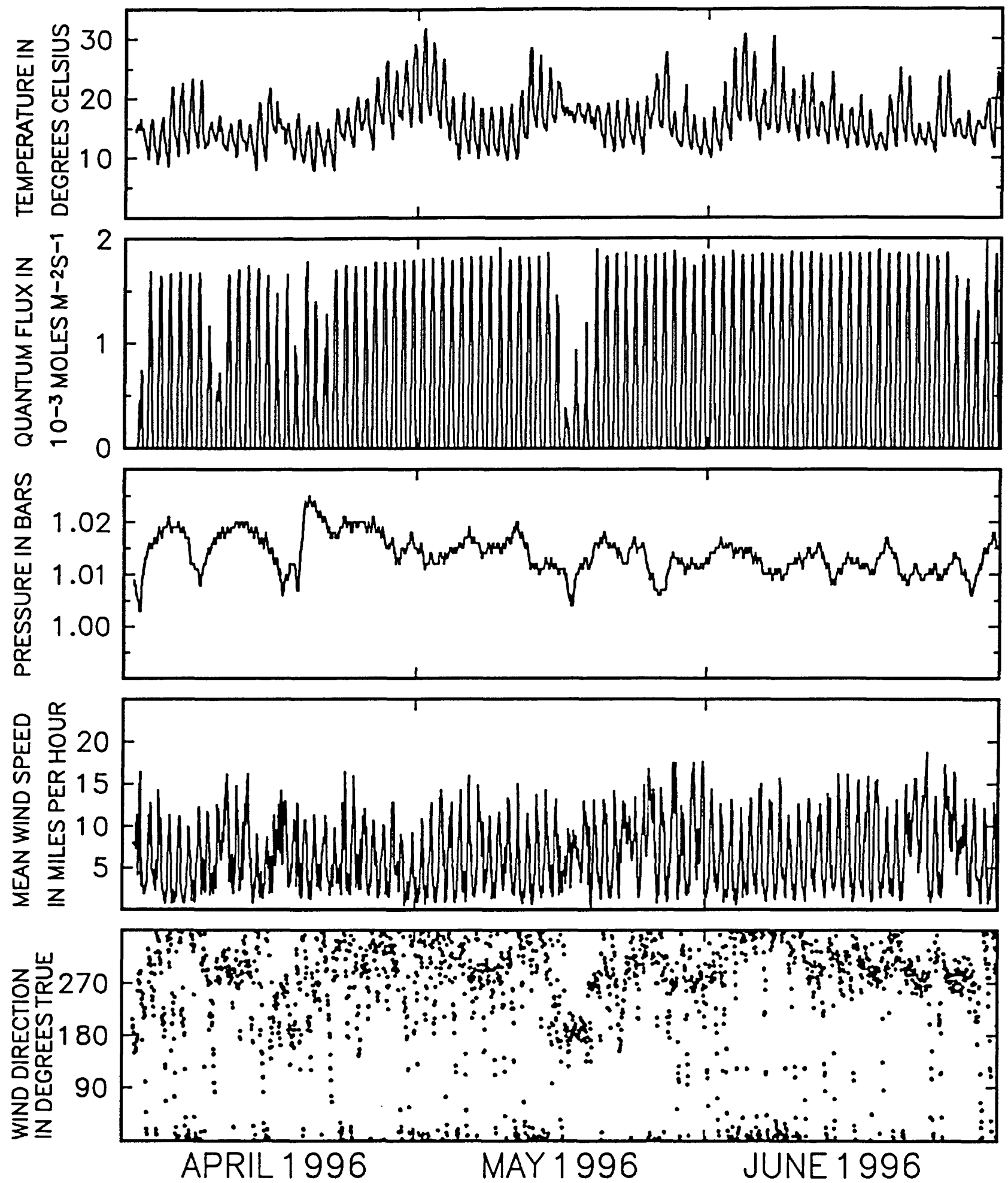

Figure 15. Time series plots of hourly values for mean temperature, quantum flux, pressure, mean wind speed, and wind direction at the Port of Redwood City for April-June, 1996. 

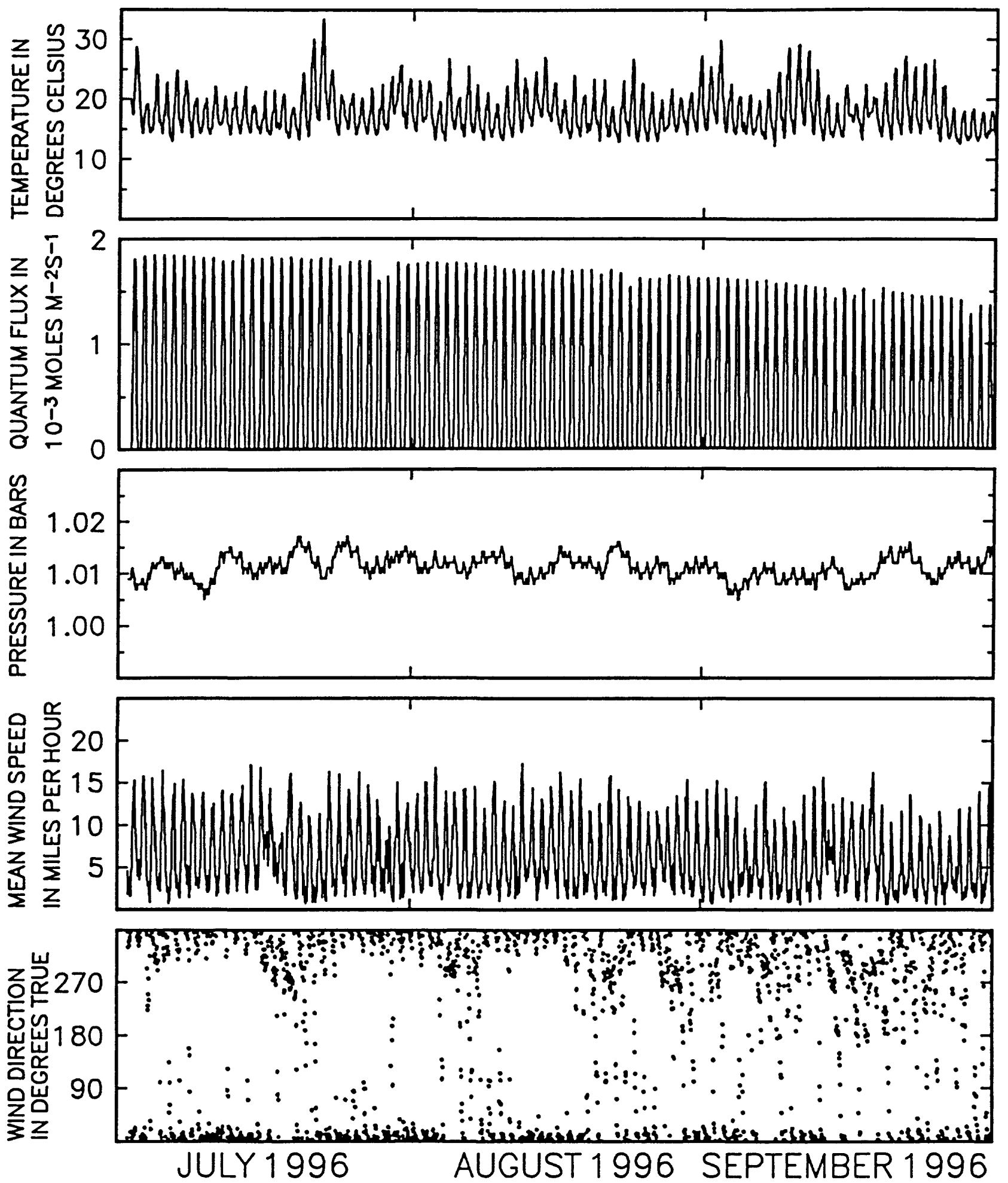

Figure 16. Time series plots of hourly values for mean temperature, quantum flux, pressure, mean wind speed, and wind direction at the Port of Redwood City for July-September, 1996. 

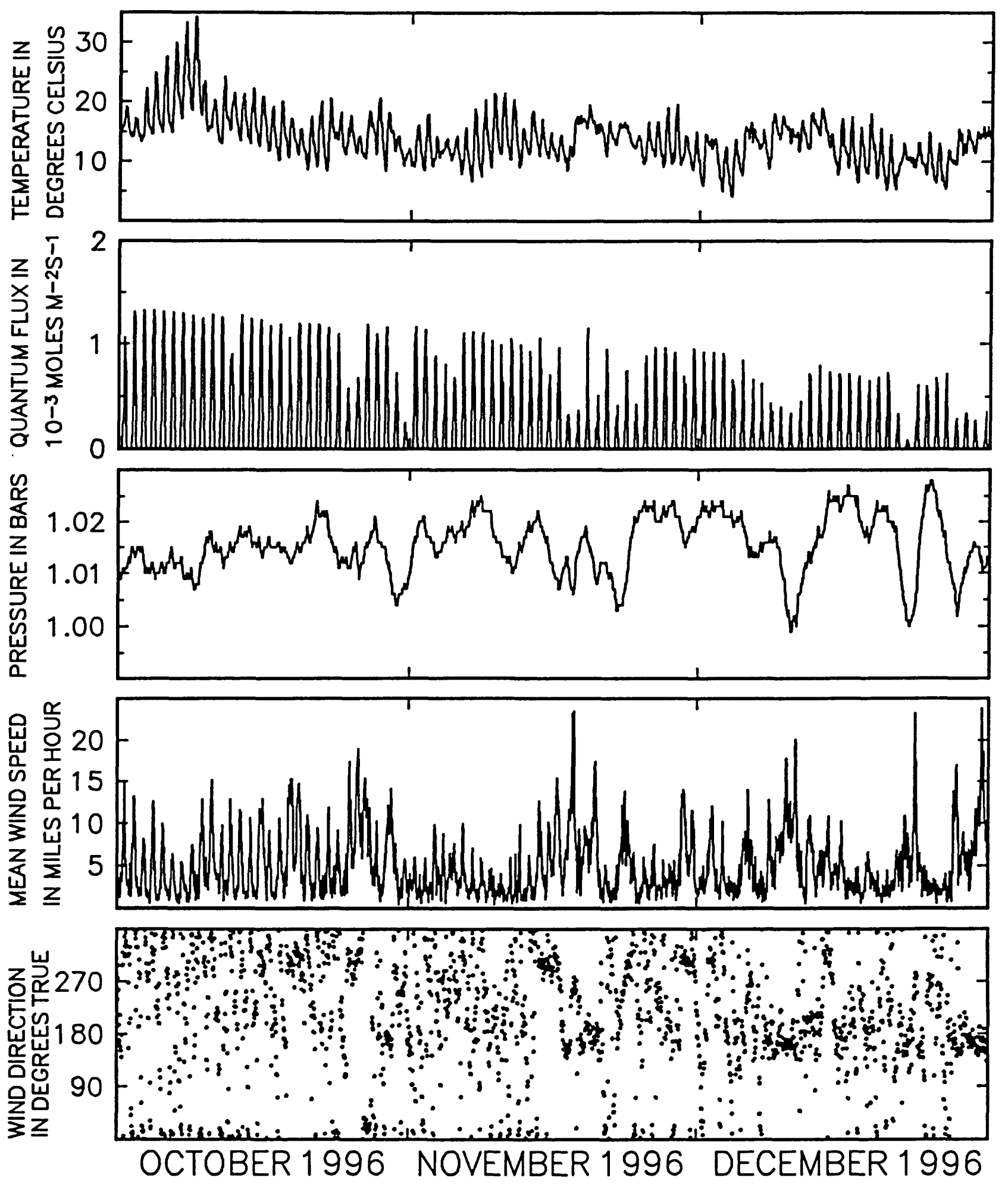

Figure 17. Time series plots of hourly values for mean temperature, quantum flux, pressure, mean wind speed, and wind direction at the Port of Redwood City for October-December, 1996. 

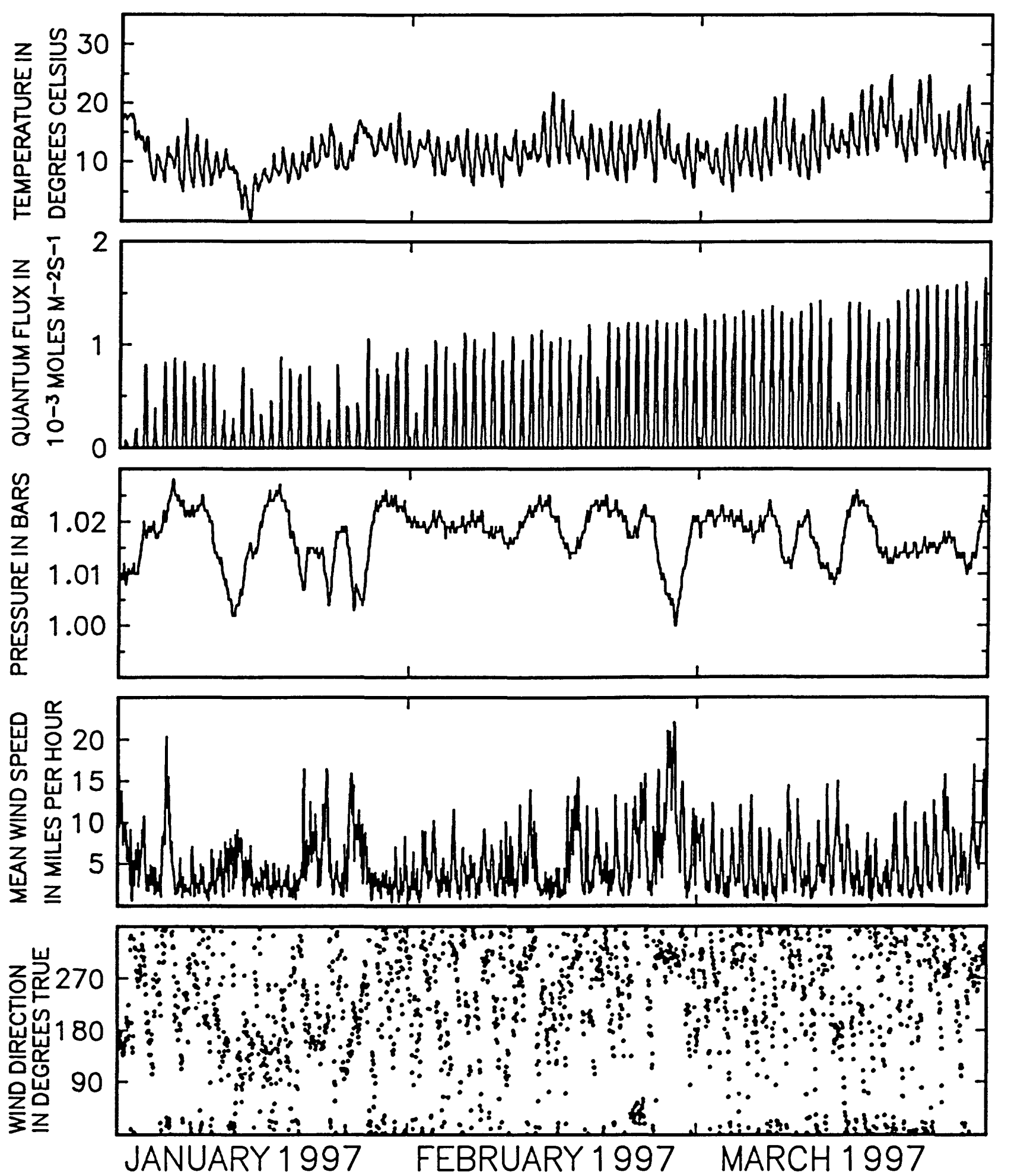

Figure 18. Time series plots of hourly values for mean temperature, quantum flux, pressure, mean wind speed, and wind direction at the Port of Redwood City for January-March, 1997. 

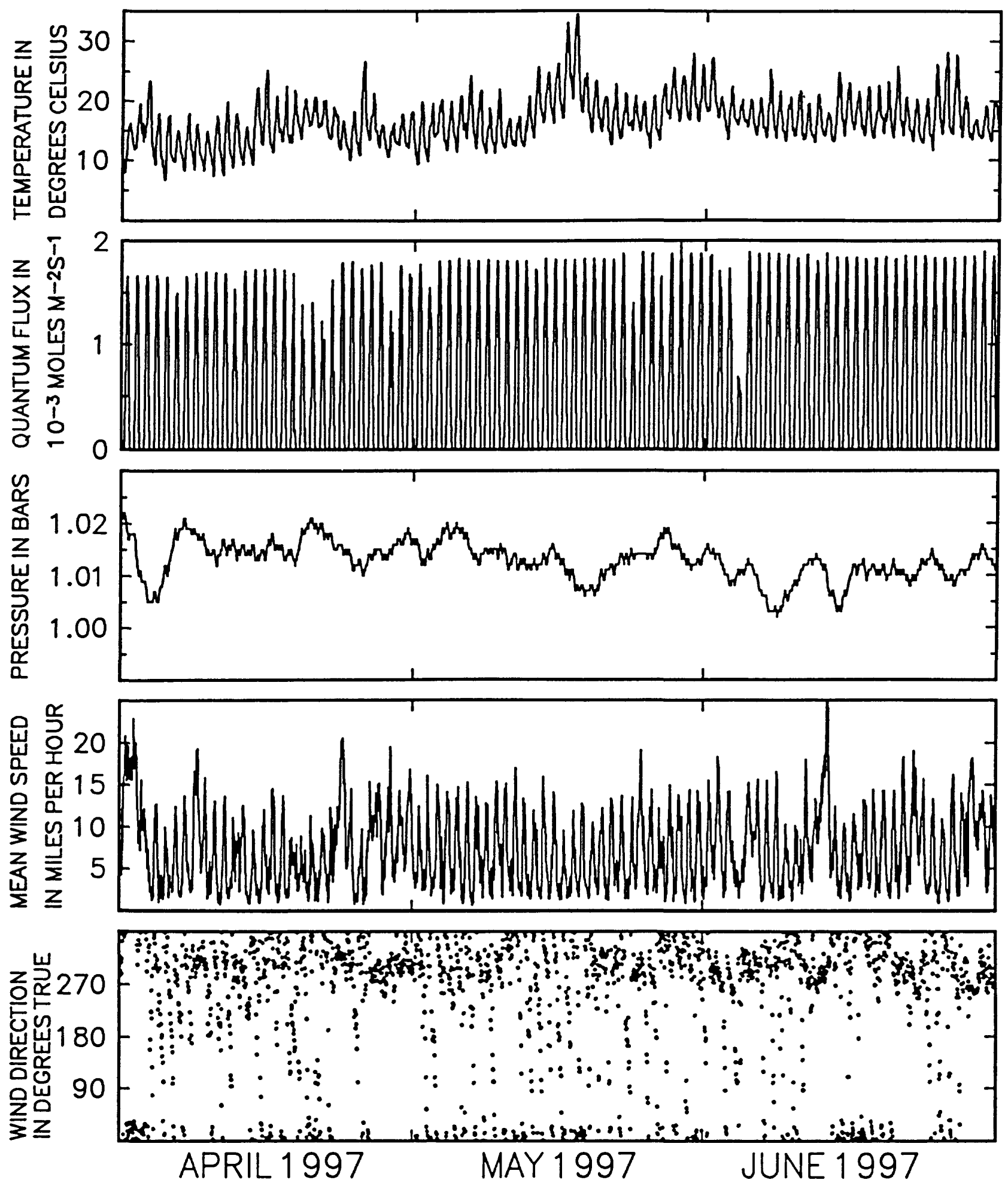

Figure 19. Time series plots of hourly values for mean temperature, quantum flux, pressure, mean wind speed, and wind direction at the Port of Redwood City for April-June, 1997. 

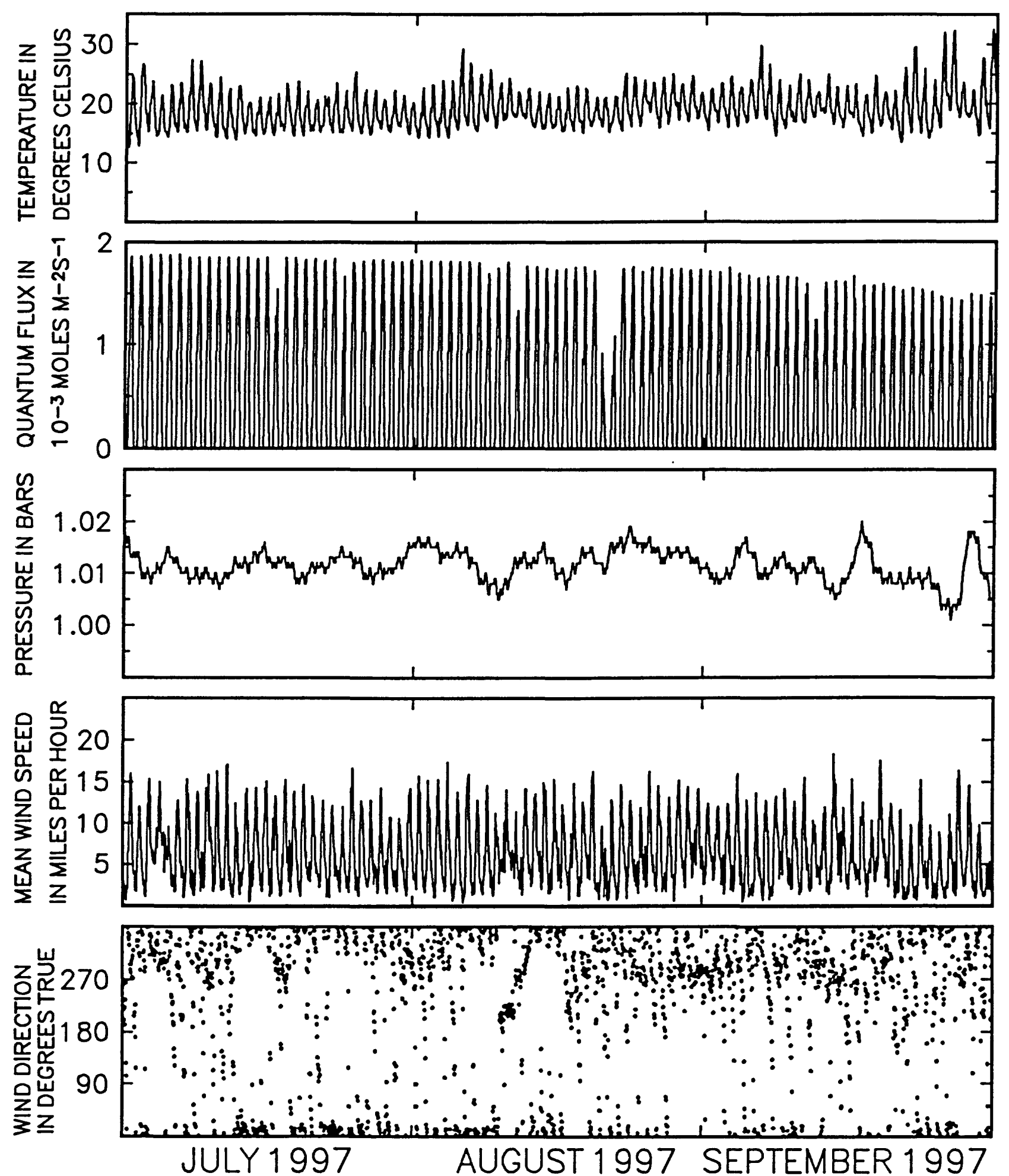

Figure 20. Time series plots of hourly values for mean temperature, quantum flux, pressure, mean wind speed, and wind direction at the Port of Redwood City for July-September, 1997. 

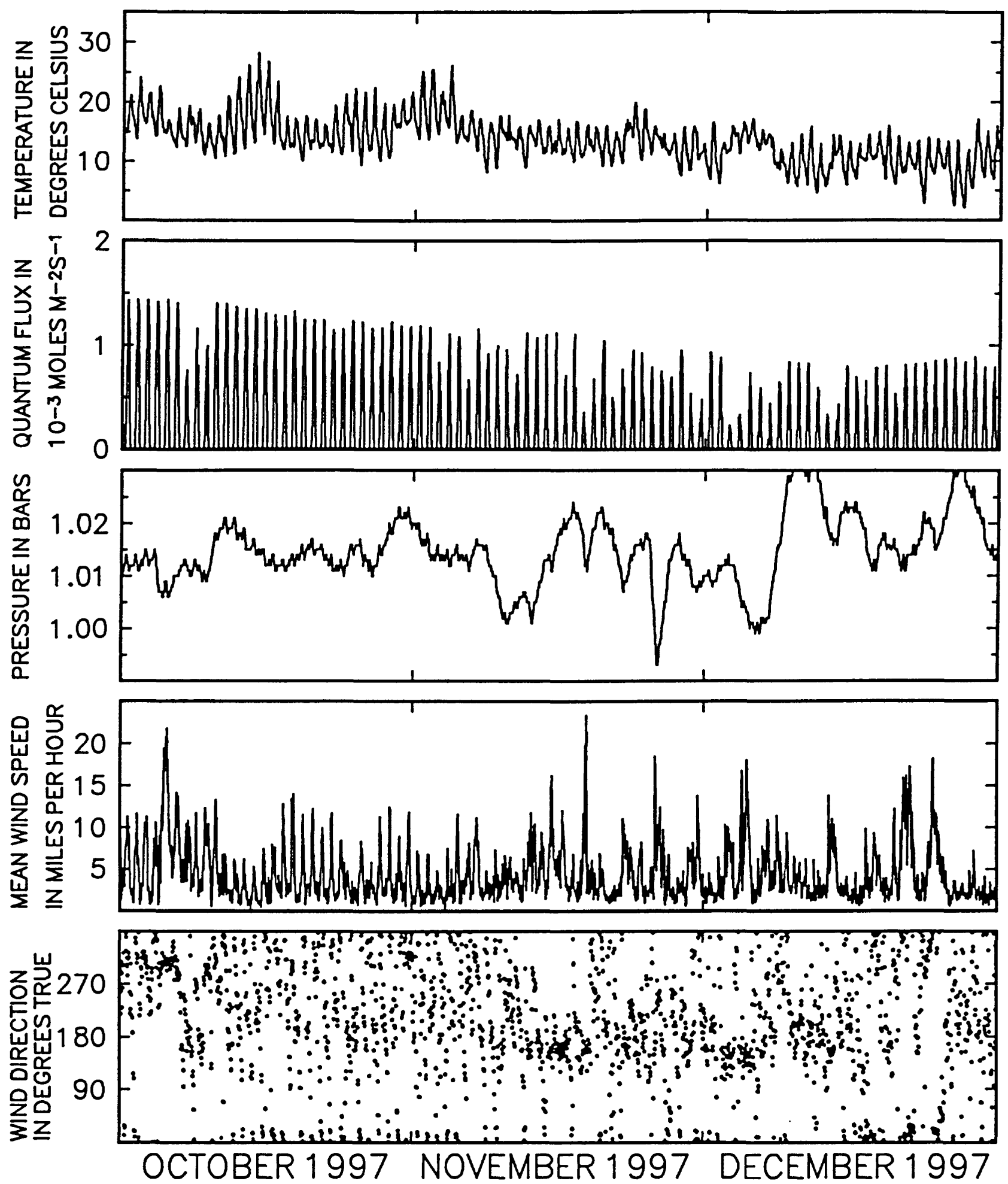

Figure 21. Time series plots of hourly values for mean temperature, quantum flux, pressure, mean wind speed, and wind direction at the Port of Redwood City for October-December, 1997. 